\title{
CHARACTERISTIC LIGNOCELLULOSE OF SAGO SOLID WASTE FOR BIOGAS PRODUCTION
}

\author{
Nururrahmah Hammado ${ }^{1 *}$, Sudarno Utomo ${ }^{2}$, Budiyono ${ }^{2}$ \\ ${ }^{1}$ School of Postgraduate Studies, Diponegoro University, Semarang, Indonesia \\ ${ }^{2}$ Diponegoro University, Faculty of Engineering, , Semarang, Indonesia
}

Biogas is an alternative energy that can be produced from various biomass, sago solid waste is one of them. Sago solid waste was obtained from processing sago stems into sago starch. Sago solid waste should be treated to separate lignocellulose that can be used as raw material for biogas production. In this study, pre-treatment was done to anaerobic fermentation. Physical pre-treatment was done by milling the biomass into small pieces. Chemical pre-treatment was done by using $\mathrm{NaOH}$ solvent, and biological pre-treatment used a microbial consortium. Characterization of pretreated sago solid waste was analyzed with Scanning Electron Microscopy (SEM) combined with Energy Dispersive X-Ray (EDX) for inorganic element composition analysis. The functional group changes were characterized by Fourier Transform Infrared (FTIR) and lignocellulosic composition was analyzed by the Van Soest method. The analysis of results showed that chemical and biological pretreatment significantly degradation lignocellulose than other methods based on morphologies of sago hampas granules. The biological pre-treatment was capable of degraded lignin up to $3.47 \%$ and hemicellulose $8.01 \%$.

Key words: sagusolid waste, biomass, lignocellulose, pretreatment, biogas

\section{INTRODUCTION}

Indonesia is one of the countries having the largest sago plantation in the world. The Plantation Statistic of Indonesia recorded the vast of sago plantations up to 2017 reached 219.978 ha with the production total was 487.643 tons [1].Those plantations widespread in some areas, which were Sumatera 106.179 ha (Aceh, Riau, and Riau Island), Kalimantan 9.181 ha (West Kalimantan, South Kalimantan and East Kalimantan), Maluku and Papua 87.264 ha (Maluku, North Maluku, Papua and West Papua), and Sulawesi 17.354 ha (Central Sulawesi, South Sulawesi, West Sulawesi and South East Sulawesi).

The sago plantation area in South Sulawesi is 3.896 ha with production total is $2.560 \mathrm{t}$ and the productivity is $1.217 \mathrm{~kg} / \mathrm{ha} /$ year [1] they were potentially grown as new foods of rice replacement. Sago can to produce about $200 \mathrm{~kg}$ of wet sago flour every year and dried starch 25 ton/ ha with carbohydrate $84.7 \mathrm{~g}$ per $100 \mathrm{~g}$ of materials [2]. The sago starch could be got from the extraction. The extraction method is divided into two methods, such as traditional and modern methods. The principles of those sago extraction methods are similar, thus the difference lays on the operation scale [3] and the technology on the extraction process [4].

The extraction process is proceeded through some processes, which are mature sago trees to be cut down, split and skinned, the sago stems are shredded and extracted to be drawn aside the sago starch, dried up and packed [5]. The extraction process of sago starch is using a lot of water so is producing wastewater and solid waste. The solid waste is the pith of sago fibrous (sago solid waste) and sago bark.
Table 1: Contents of sago solid waste

\begin{tabular}{|c|c|}
\hline Component & Percentage (\%) \\
\hline Starch & 65,7 \\
\hline Crude Fiber & 14,8 \\
\hline Protein & 1 \\
\hline Fat & 0,20 \\
\hline Ash & 4,1 \\
\hline Water & 59,1 \\
\hline Source: [6]
\end{tabular}

Table 1 showed the contents of sago solid waste for $65.7 \%$, with the residue contents are crude fiber, protein, fat, ash, and water.

Table 2: Physical and chemical characteristics of sago solid waste

\begin{tabular}{|c|c|}
\hline Parameter & Composition \\
\hline Nitrogen total (\%) & 1,66 \\
\hline $\mathrm{P}_{2} \mathrm{O}_{5}(\%)$ & 0,04 \\
\hline C-Organic (\%) & 33,01 \\
\hline Ratio C/N & 20 \\
\hline Calsium (ppm) & 27716 \\
\hline Magnesium (ppm) & 4247 \\
\hline Sulfur (ppm) & 743 \\
\hline Source: [7]
\end{tabular}

Table 2 showed the result of the study that the dried sago solid waste still contains high C-organic 33.01\% [7], while the lignin residue in the wet sago solid waste 
is $21 \%$, cellulose $20 \%$, the residu is mineral, extractive substance, and ash [8]. The content of sago pulp is studied by Linggang [9] and the resulted is sago solid waste contained starch $58 \%$, cellulose $23 \%$, hemicellulose 9.2\% and lignin $3.9 \%$ got from the hydrolysis process using cellulolytic enzyme.

The composition of lignocellulose in the sago solid waste is high enough to affect the environmental damage buried for a long time will create a stink and allow the leachate water flow to the waters. Utami et al., [10] reported that the composition of lignocellulose of sago is high, which is cellulose $11 \%$, hemicellulose $7.6 \%$, and lignin $12 \%$. The potency of sago solid waste contained in the lignocellulose can be used further as other products: as the materials to create bioethanol [11], as absorbent of heavy metal in the wastewater treatment [12], medium of fungus growth [13], the materials of making the single-cell protein [14], and its potency as energy source [15].

The main components composing the lignocellulose are lignin, cellulose, and hemicellulose. Lignin is the natural polymer as the binding-material of cellulose and hemicellulose so that creating the strong and hard stem structures. That is the reason why the sago solid waste before converted to biogas needs delignification to degrade cellulose form sugar [16]. The delignification is a process to decide the lignin bound of biomass and affect the lignin structure damaged until cellulose and hemicellulose bonded in the lignocellulose can be released [17].

The conversion of sago solid waste by biogas needs pretreatment to damage the lignocellulose structure so then the enzyme was easy to work in the hydrolysis process. The pretreatment method refers to the use of physically, chemically and biologically. The various types of physical pretreatment such as crushing and grinding to increase the particle sizes [18]. Chemical pretreatment using a base solvent $[19,20,21,22]$ and acid solvent $[23,24]$ that can damage the bounding in lignocellulose.

Physical pretreatment using mechanical comminution to reduce the particle size and crystallinity $[25,26]$, by radiation can decrease the composition of lignin and hemicellulose [27, 28, 29]. The biological pretreatment using fungus [30, 31, 32], using microbial consortium [33], and enzymatically $[34,35]$ can degrade the lignin and hemicellulose but the cellulose is degraded because more resistant to microorganism [36].

Lignocellulosic characteristics of biomass are important in anaerobic digestion because it can affect the volume of biogas produced. This research focuses on the pretreatment effect of sago solid waste as biomass for anaerobic digestion. This study determines the proper method of pretreatment of sago solid waste to produce optimal biogas.

\section{MATERIALS AND METHODS}

\section{Materials}

The sago solid waste was taken from Luwu District, South Sulawesi. The wet sago solid waste was gained from sago processing washed and separated from the contaminant before treatment. The pretreatments of sago solid waste for lignocellulose biodegradation were done by chemically, biologically, and physically [37].

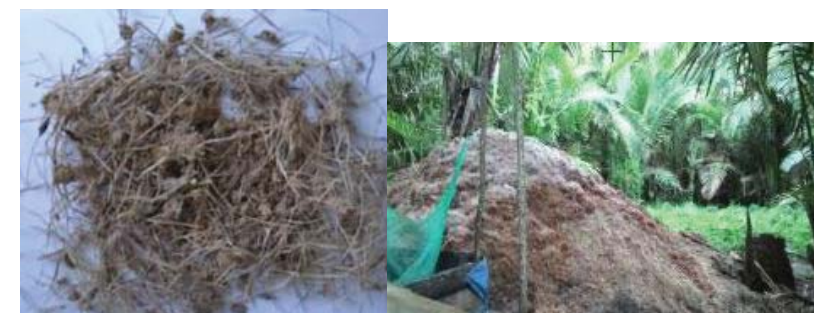

Figure 1: Samples of sago solid waste

\section{Pretreatment of biomass}

Chemical pretreatment used base solution. The base solution $\mathrm{NaOH}$ used in this research to study the effect of chemical pretreatment because effective for lignocellulose biodegradation [38, 39, 40]. The sago solid waste was weighted at $125 \mathrm{~g}$ and added into $250 \mathrm{~mL}$ of the $\mathrm{NaOH} 0.5 \mathrm{M}$. The sago solid waste was stirred evenly still submerged and then stored at room temperature for 48 hours.

The microbialconsortium used for the biological pretreatment [41]. The experiment was started by dissolved $100 \mathrm{~g}$ of consortium microbe into $1000 \mathrm{~mL}$ of solution and stored at room temperature for 24 hours. The sago solid waste was weighted at $125 \mathrm{~g}$ and mixed into $250 \mathrm{~mL}$ of consortium microbe. The mixing solution stored at room temperature for 48 hours.

The physical pretreatment was done by grinding the sago solid waste to increase the size of the particle surface area of crystalline [42]. The sago solid waste was weighted at $125 \mathrm{~g}$ and added into $250 \mathrm{~mL}$ of solution. The sago solid waste blended at average speed and kept at room temperature for 48 hours.

\section{Lignocellulose characterization}

FTIR is used for the investigation of a functional group of macromolecules. The change in the functional group of the sample was characterized by FTIR. The spectra of the sample were collected from $4000-200 \mathrm{~cm}^{-1}$ by Perkin Elmer Type Frontier (SNI 19-4370-2004 method). The sago solid waste were dried at room temperature and weighted at $2 \mathrm{mg}$ mixed into $200 \mathrm{mg} \mathrm{KBr}$. The mixing samples were blended and homogenized, and then compacted and measured by spectrometer FTIR [43, 44]. The number of points at 3601 with the interval data $1 \mathrm{~cm}^{-1}$ up to $400 \mathrm{~cm}^{-1}$.

The morphology analysis of sago solid waste was observed using Scanning Electron Microscope [45, 46] and 
combination with Energy Dispersive X-Ray Spectroscopy (EDX) to determine the composition of inorganic elements and compounds in the material. The morphology surfaces were characterized using Au. A Jeol (model JSM-6510 LA) at 500-5000x magnification and the percentage composition of elements and compounds was weight at 3000x magnification by the counting rate of $2084 \mathrm{cps}$ on the energy range 0-20 KeV.

The composition of lignin, cellulose, and hemicellulose on the sago solid waste was analyzed using the Van Soest method (1970) with $\mathrm{H}_{2} \mathrm{SO}_{4} 72 \%$. The effect of different pretreatment methods on the composition of lignin, cellulose, and hemicellulose was analyzed using linear regression analysis.

\section{RESULTS AND DISCUSSION}

\section{FTIR analysis}

FTIR analysis was used to investigate the degradation in the functional groups on lignocellulose caused by pretreatment on the samples. The peaks intensities created on the FTIR spectrum showed the specific functional group on organic compounds [47]. Figure 2 shows the FTIR analysis before and after pretreatment.

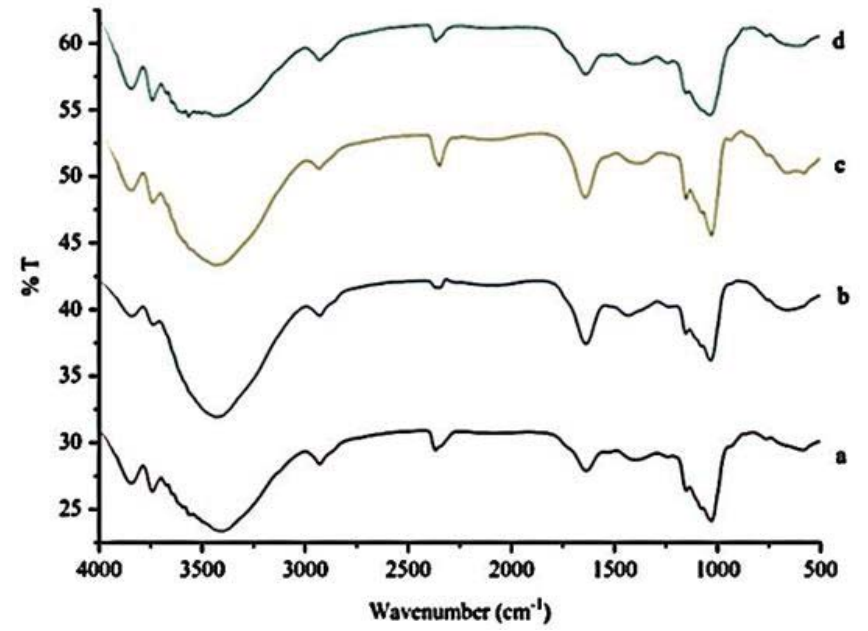

Figure 2: FTIR comparative spectra of sago solid waste:

(a) before pretreatment, (b) biological pretreatment,

(c) chemical pretreatment, (d) physical pretreatment
FTIR spectra showed two groups of peak intensities, which were the wavenumber with the low on 1650-1600 $\mathrm{cm}^{-1}$, and wavenumber with high on $3500-2900 \mathrm{~cm}^{-1}$. The similarity on the spectrum showed that the changes in the functional group were due not so different pretreatment, some spectrums appeared on certain wavenumber that showed delignification.

Table 3 showed the infrared absorbance area of sago solid waste before and after pretreatment. The wavenumber area was shown before and after pretreatment appearance at wavelength 3397.47 ; 3423.37; 3430.25; and $3565.65 \mathrm{~cm}^{-1}$, showed the organic functional group for $\mathrm{O}-\mathrm{H}$ stretch (alcohol and phenol) that were available on lignin; C-H for alkyl group that was corresponds to an cellulose structure at wavelength 2929.38; 2933.10; 2929.78; and $2930.19 \mathrm{~cm}^{-1}[42,43,47,48]$. The peak values wavenumber appeared on the area 1636.40; 1640.85; 1637.83; and $1638.44 \mathrm{~cm}^{-1}$ for group $\mathrm{C}=\mathrm{C}$ aromatic, and wavenumber for group $\mathrm{C}-\mathrm{O}$ symmetric lignin, cellulose, and hemicellulose on the areas 1028.63; 1027.98; 1032.07; and $1036 \mathrm{~cm}^{-1}$.

The peak values at area 1432.49 and $1402.63 \mathrm{~cm}^{-1}$ showed the group deformation $-\mathrm{CH}_{2}$ on lignin and cellulose [49]. This wavenumber area just appeared on biological and physical pretreatment. The peaks on that area were caused by the binding extension of phenol-ether on lignin [50] and the breakage of hemicellulose from lignin [51]. A strong absorption was seen around $1152.79 \mathrm{~cm}^{-1}$ on the biological pretreatment which is assigned for group $\mathrm{C}-\mathrm{O}-\mathrm{C}$ asymmetric to cellulose and hemicellulose due to lignin degraded [52].

The peak value appeared on $1373.64 \mathrm{~cm}^{-1}$ showed methyl group $\left(-\mathrm{CH}_{3}\right)$ caused by the lignin degraded becoming cellulose and hemicellulose $[48,52,53]$ due to the usage of $\mathrm{NaOH}$ on the chemical pretreatment. The degradation was strengthened by the wavelength that appeared on $1152.43 \mathrm{~cm}^{-1}$ for the group of C-O-C asymmetry on the bonds of lignin-cellulose and hemicellulose-lignin. The displacement of wavenumbers showed that alteration in lignocellulose caused by pretreatments. Lignin was a protection layer of cellulose that had to be eliminated because could disturb the microorganisms in the process of biogas production.

Table 3: Infrared absorbance area of sago solid waste before and after the pretreatment

\begin{tabular}{|c|c|c|c|c|}
\hline \multicolumn{4}{|c|}{ Wavenumber $\left(\mathrm{cm}^{-1}\right)$} & \multirow{2}{*}{ Functional group } \\
\cline { 1 - 3 } Before pretreatment & Chemical & Biological & Physical & \\
\hline 3397.47 & 3423.37 & 3430.25 & 3565.65 & O-H stretching \\
\hline 2929.38 & 2933.10 & 2929.78 & 2930.19 & C-H stretching \\
\hline 1636.40 & 1640.85 & 1637.83 & 1638.44 & C=C aromatic \\
\hline- & - & 1432.49 & 1402.63 & $-\mathrm{CH}_{2}$ deformation \\
\hline- & 1373.64 & - & - & $-\mathrm{CH}_{3}$ \\
\hline- & 1152.43 & 1152.79 & - & C-O-C asymmetric \\
\hline 1028.63 & 1027.98 & 1032.07 & 1036 & C-O symmetric \\
\hline
\end{tabular}




\section{Analysis of lignocellulose morphology using SEM-EDX}

The sago solid waste pretreatment caused the changes from the structure of morphology lignocellulose. SEM analysis was used to see the changes of sago solid waste morphology before and after the pretreatments combined with EDX. The compositions of compounds in the samples were viewed and analyzed using EDX. Figure 3 showed the sago solid waste morphology before and after pretreatment. The sago solid waste morphology before pretreatment (Fig.3a) smoother, poreless, eggshaped and irregular as well as the sago starch granule found from Leyte, Philippines which came in the eggshaped as the chime [45], and the sago starch extracted from sago pith waste (SPW) [54]. The pretreatments given on the sago solid waste caused the changes in morphology structures.

The sago solid waste morphology after chemical pre-

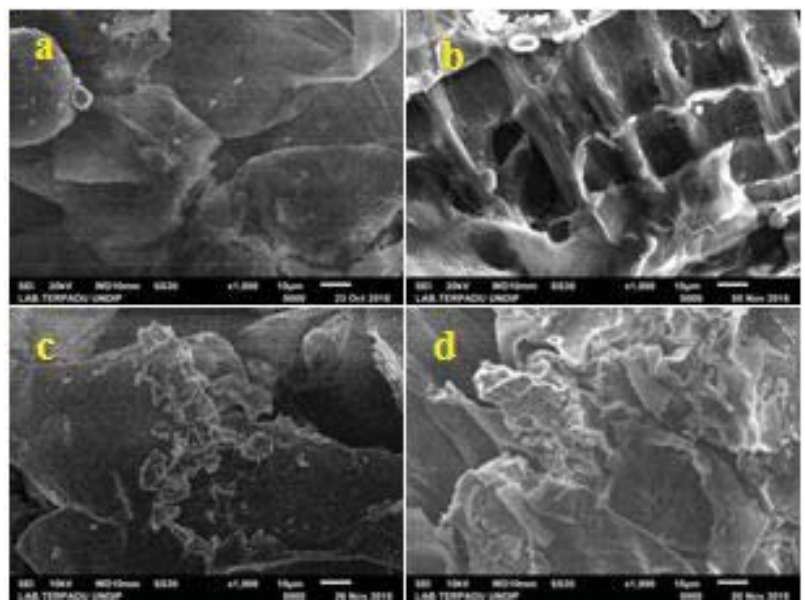

Figure 3: SEM of sago solid waste with magnification 1000x on various treatments: (a) before treatment,

(b) chemical pretreatment, (c) biological pretreatment, (d) physical pretreatment treatment (Fig.3b) became opened and the surface was perforated with more well-ordered shaped and rough. The morphology change was caused by the $\mathrm{NaOH}$ addition lignin degraded on the crystalline and amorfthen separated cellulose and hemicellulose from the bond of lignin [52]. Figure 3c showed the morphology of sago solid waste after biological pretreatment. The morphology resulted in the picture showed the irregular surface and some parts having rough surface caused by all parts of lignocellulose were not degraded. The microorganism used to degrade lignin and hemicellulose was more resistant to the activities of microorganisms so there was a small amount of degraded cellulose [36].

Figure $3 d$ showed the morphology of sago solid waste after physical pretreatment. Physical pretreatment was done using a blender to reduce the size of sago solid waste particles to facilitate the process of lignocellulose degradation [54]. The morphology of sago solid waste after pretreatment showed a very irregular, rough surface, but still some smooth surfaces. The particle size not to be the same size caused by the process of crushing with a blender caused there are still some parts with large particle sizes.

Table 4 showed the composition analysis of the compounds contained in the sample using EDX. The main component in the sample before and after pretreatment showed an increase of carbon concentration with a level of $80.00 ; 80.40 ; 94.83$; and $90.78 \%$ followed by decrease $\mathrm{SiO}_{2}$ concentration of $18.02 ; 15 ; 2.80 ;$ and $7.65 \%$. Macro and microelements found in the bark are absorbed from soil nutrients, such as $\mathrm{Ca}, \mathrm{Mg}, \mathrm{Al}$, and $\mathrm{Na}$. Chemically treated samples produced $\mathrm{NaOH}$ compounds which showed that was still a residual solvent used to degrade as much as $4.19 \%$ lignin that was not found in the sample with other treatments. While biological pretreatment produces $\mathrm{Na}_{2} \mathrm{O}$ compounds as much as $0.26 \%$. This showed that the microorganism used can break the bond of lignin and the $\mathrm{Na}^{+}$ion will bind to lignin.

Tabel 4: Results of EDX analysis of sago solid waste before and after pretreatments

\begin{tabular}{|c|c|c|c|c|}
\hline Compound & $\begin{array}{c}\text { Before } \\
\text { pretreatment } \\
(\% w)\end{array}$ & $\begin{array}{c}\text { Chemical } \\
(\% \mathrm{w})\end{array}$ & $\begin{array}{c}\text { Biological } \\
(\% \mathrm{w})\end{array}$ & $\begin{array}{c}\text { Physical } \\
\text { (\%w) }\end{array}$ \\
\hline Carbon, C & 80.00 & 80.40 & 94.83 & 90.78 \\
\hline $\begin{array}{c}\text { Sodium, Hydrokxide, } \\
\mathrm{NaOH}\end{array}$ & - & 4.19 & - & - \\
\hline Silica Dioxide, $\mathrm{SiO}_{2}$ & 18.08 & 15.00 & 2.80 & 7.65 \\
\hline $\begin{array}{c}\text { Calsium Oxide, } \\
\mathrm{CaO}\end{array}$ & 1.31 & 0.41 & 2.11 & 1.57 \\
\hline Alumina, $\mathrm{Al}_{2} \mathrm{O}_{3}$ & 0.24 & - & - & - \\
\hline $\begin{array}{c}\text { Magnesium Oxide, } \\
\text { MgO } \\
\end{array}$ & 0.37 & - & - & - \\
\hline $\begin{array}{l}\text { Natrium Oxide, } \\
\qquad \mathrm{Na}_{2} \mathrm{O} \\
\end{array}$ & - & - & 0.26 & - \\
\hline
\end{tabular}




\section{Lignocellulose analysis}

The content of cellulose and hemicellulose sago solid waste increased after pretreatment, while the lignin content decreases. Table 5 shows the results of the lignocellulosic analysis of sago solid waste before and after pretreatment.

Very large decrease in lignin content occurred in biological pretreatment as much as $3.47 \%$ and decreased hemicellulose content as much as $8.01 \%$, while cellulose content increased as much as $7.62 \%$ lower than other pretreatments. The microorganisms work caused by specifically degrade lignin and hemicellulose but only a small portion of cellulose can be degraded due to the nature of cellulose that was resistant to microorganisms [36].

The effect of giving sago solid waste pretreatment to changes in lignocellulosic composition showed based on the results of testing using linear regression.

$\mathrm{F}$ test results obtained calculated $\mathrm{F}$ value for lignin and hemicellulose at 35,178 (Table 6) and 13,598 so that when compared with the $F$ value of the interpolated table, which is 4.75 , the calculated $F$ value $>\mathrm{F}$ table.

The calculated $F$ value for lignin is $35,178>4.75$ for the $\mathrm{F}$ table, while the calculated $\mathrm{F}$ value for hemicellulose is $13,598>4.75$. This showed that the regression equation is stated to be meaningful.

Similarly, by comparing the standard significant value with the significant value of the analysis results, obtained significant levels of lignin and hemicellulose are smaller than the standard significant value, which was $0,000<0.05$ for lignin and $0.002<0.05$ for hemicellulose (Table 7). The results showed that there was an effect of pretreatment on changes in the composition of lignin and hemicellulose sago solid waste and were very significant and considerably different.

$F$ test results showed for cellulose are different from lignin and hemicellulose. The calculated $F$ value obtained 1.751 value is smaller than the $F$ value of table $4.75(F$

Table 5: Lignocellulosic analysis of sago solid waste before and after pretreatments

\begin{tabular}{|c|c|c|c|c|}
\hline Compound & $\begin{array}{c}\text { Before } \\
\text { pretreatment } \\
(\%)\end{array}$ & $\begin{array}{c}\text { Chemical } \\
(\%)\end{array}$ & $\begin{array}{c}\text { Biological } \\
(\%)\end{array}$ & $\begin{array}{c}\text { Physical } \\
(\%)\end{array}$ \\
\hline Lignin & 6.26 & 5.36 & 2.73 & 5.68 \\
\hline Cellulose & 12.08 & 30.40 & 19.74 & 30.72 \\
\hline Hemicellulose & 12.83 & 14.58 & 4.84 & 13.92 \\
\hline
\end{tabular}

Table 6: Regression analysis of sago solid waste pretreatment on lignin composition

\begin{tabular}{|l|l|c|c|c|c|c|}
\hline \multicolumn{7}{|c|}{ ANOVA $^{\mathrm{b}}$} \\
\hline \multicolumn{2}{|c|}{ Model } & $\begin{array}{c}\text { Sum of } \\
\text { Squares }\end{array}$ & df & $\begin{array}{c}\text { Mean } \\
\text { Square }\end{array}$ & $\mathrm{F}$ & Sig. \\
\hline \multirow{2}{*}{1} & Regression & 21.177 & 1 & 21.177 & 35.178 & $.000^{\mathrm{a}}$ \\
\cline { 2 - 7 } & Residual & 8.428 & 14 & .602 & & \\
\cline { 2 - 7 } & Total & 29.605 & 15 & & & \\
\hline
\end{tabular}

Table 7: Regression analysis of sago solid waste pretreatment on hemicellulose composition

\begin{tabular}{|l|l|c|c|c|c|c|}
\hline \multicolumn{7}{|c|}{ ANOVA $^{\mathrm{b}}$} \\
\hline \multicolumn{2}{|c|}{ Model } & $\begin{array}{c}\text { Sum of } \\
\text { Squares }\end{array}$ & df & $\begin{array}{c}\text { Mean } \\
\text { Square }\end{array}$ & $\mathrm{F}$ & Sig. \\
\hline \multirow{2}{*}{1} & Regression & 121.377 & 1 & 121.377 & 13.598 & $0^{002^{\mathrm{a}}}$ \\
\cline { 2 - 8 } & Residual & 124.962 & 14 & 8.926 & & \\
\cline { 2 - 7 } & Total & 246.339 & 15 & & & \\
\hline
\end{tabular}

calculated $1.751<\mathrm{F}$ table 4.75$)$. This showed that the regression equation becomes meaningless (Table 8) likewise, the comparison of significant values.

The significant value of the calculation result was greater than 0.207 compared to the standard significance value used of 0.05 . This showed that the pretreatment does not significantly affect cellulose changed composition.

$F$ test results showed for cellulose are different from lignin and hemicellulose. The calculated $F$ value obtained 1.751 value is smaller than the $F$ value of table $4.75(F$ calculated $1.751<\mathrm{F}$ table 4.75 ). This showed that the regression equation becomes meaningless (Table 8) likewise, the comparison of significant values.

Table 8: Regression analysis of sago solid waste pretreatment on cellulose composition

\begin{tabular}{|l|l|l|c|c|c|c|}
\hline \multicolumn{7}{|c|}{ ANOVA $^{\mathrm{b}}$} \\
\hline \multicolumn{2}{|c|}{ Model } & $\begin{array}{c}\text { Sum of } \\
\text { Squares }\end{array}$ & df & $\begin{array}{c}\text { Mean } \\
\text { Square }\end{array}$ & $\mathrm{F}$ & Sig. \\
\hline \multirow{2}{*}{1} & Regression & 108.601 & 1 & 108.601 & 1.751 & $.207^{\mathrm{a}}$ \\
\cline { 2 - 8 } & Residual & 868.341 & 14 & 62.024 & & \\
\cline { 2 - 7 } & Total & 976.942 & 15 & & & \\
\hline \multicolumn{7}{|l|}{ a. Predictors (Constant): Perlakuan } \\
\hline \multicolumn{2}{|l|}{ b. Dependent Variable: Selulosa } \\
\hline
\end{tabular}


The significant value of the calculation result was greater than 0.207 compared to the standard significance value used of 0.05 . This showed that the pretreatment does not significantly affect cellulose changed composition.

\section{CONCLUSION}

Lignocellulose degradation to separate lignin, cellulose, and hemicellulose needs to be carried out before converted into biogas. FTIR results showed changes in wavenumber absorption in biological and chemical pretreatment which shows the deformation of the $-\mathrm{CH}_{2}$ $\mathrm{CH}_{3}$ groups in lignin and cellulose, as well as C-O-C groups for cellulose and hemicellulose. The results of SEM-EDX analysis showed that the morphology of sago solid waste after pretreatment had a rougher, opened, and perforated surface but left the $\mathrm{NaOH}$ compound for chemical pretreatment and $\mathrm{Na}_{2} \mathrm{O}$ for biological pretreatment. The results of the analysis of the composition of lignocellulose showed a decrease in lignin and hemicellulose content of $3.47 \%$ and $8.01 \%$, and cellulose content increased by $7.62 \%, 18.29 \%$, and $18.60 \%$. Although chemical, biological, and physical sago solid waste pretreatment has been shown by the results of the analysis, further research is still needed to obtain information on the conditions of pretreatment that can provide the most effective results to increase biogas production.

\section{ACKNOWLEDGMENTS}

This research was supported by LPDP as a funding sponsorship for financial support.

\section{REFERENCES}

1. Perkebunan, D.J. (2016). Statistik perkebunan Indonesia 2015-2017. Direktorat Jendral Perkebunan Kementerian Pertanian, Jakarta.

2. Nggobe, M. (2005). The utilizing by product of sago as feed for poultry in Papua. Eight International Sago Symposium in Jayapura, Indonesia. Japan Society for the Promotion Science.

3. Karim, A., Tie, A., Manan, D., Zaidul, I. (2008). Starch from the sago (Metroxylon sagu) palm tree properties, prospects, and challenges as a new industrial source for food and other uses. Comprehensive Reviews in Food Science and Food Safety, vol. 7, no. 3, 215-228, DOI: 10.1111/j.1541-4337.2008.00042.x.

4. Greenhill, A.R. (2006). Food safety and security of sago starch in rural Papua New Guinea, James Cook University, from http://researchonline.jcu.edu. au/2023/2.

5. Awg-Adeni, D., Abd-Aziz, S., Bujang, K., Hassan, M. (2010). Bioconversion of Sago Residue into Value Added Products. African Journal of Biotechnology, vol. 9, no.14, 2016-2021.
6. Abd-Aziz, S. (2002). Sago starch and its utilisation. Journal of Bioscience and Bioengineering, vol. 94, no. 6, 526-529, DOI: 10.1016/S13891723(02)80190-6.

7. Nururrahmah, H., Sudarno, U. (2018). Physicochemical characteristic of sago solid waste and sago wastewater in Luwu Regency. E3S Web of Conferences. EDP Sciences. vol. 73, p. 07007, DOI: 10.1051/e3sconf/20187307007.

8. Lim, J.K. (2006). Preparation and characterization of carboxymethyl sago waste and its hydrogel, Universiti Putra Malaysia.

9. Linggang, S., Phang, L., Wasoh, M., Abd-Aziz, S. (2012). Sago pith residue as an alternative cheap substrate for fermentable sugars production. Applied Biochemistry and Biotechnology, vol. 167, no. 1, 122-131, DOI: 10.1007/s12010-012-9592-0.

10. Utami, A.S., Sunarti, T.C., Isono, N., Hisamatsu, M., Ehara, H. (2014). Preparation of biodegradable foam from sago residue. Sago Palm, vol. 22, 1-5.

11. Dhiputra, K., Made, I., Jonatan Numberi, J., Ekayuliana, A. (2015). Pemanfaatan ampas ela sagu sebagai bioetanol untuk kebutuhan bahan bakar rumah tangga di Provinsi Papua. Seminar Nasional Tahunan Teknik Mesin Indonesia XIV.

12. Karthika, C., Vennilamani, N., Pattabhi, S., Sekar, M. (2010). Utilization of sago waste as an adsorbent for the removal of $\mathrm{Pb}$ (II) from aqueous solution: kinetic and isotherm studies. International Journal of Engineering Science and Technology,vol. 2, no. 6, 18671879, DOI: 10.1.1.168.471.

13. Sangaji, I. (2009). Mengoptimalkan pemanfaatan ampas sagu sebagai pakan ruminansia melalui biofermentasi dengan jamur tiram. Pleurotus ostreatus dan amoniasi. Bogor Agricultural University.

14. Tirta, P., Indrianti, N., Ekafitri, R. (2013). Potensi tanaman sagu (Metroxylon sp.) dalam mendukung ketahanan pangan di Indonesia. Jurnal Pangan,vol. 22, no. 1, 61-76, DOI: 10.33964/jp.v22i1.78.

15. Prastowo, B. (2015). Potensi sektor pertanian sebagai penghasil dan pengguna energi terbarukan. Perspektif,vol. 6, no. 2, 85-93, DOI: 10.21082/p. v6n2.2007.

16. Gunam, I.B.W., Wartini, N.M., Anggreni, A., Suparyana, P.M. (2011). Delignifikasi ampas tebu dengan larutan natrium hidroksida sebelum proses sakaraifikasi secara enzimatis menggunakan enzim selulase kasar dari Aspergillus niger Fnu 6018. Jurnal Teknologi Indonesia,vol. 34, no. 3, 24-32.

17. Mardina, P., Talalangi, A.I., Sitinjak, J.F., Nugroho, A., Fahrizal, M.R. (2013). Pengaruh proses delignifikasi pada produksi glukosa dari tongkol jagung dengan hidrolisis asam encer. Konversi,vo. 2, no. 2, 17-23. 
18. Mtui, G.Y. (2009). Recent advances in pretreatment of lignocellulosic wastes and production of value added products. African Journal of Biotechnology, vol. 8, no. 8, 1398-1415.

19. Chandra, R., Takeuchi, H., Hasegawa, T., Kumar, R. (2012). Improving biodegradability and biogas production of wheat straw substrates using sodium hydroxide and hydrothermal pretreatments. Energy, vol. 43, no. 1, 273-282, DOI: 10.1016/j.energy.2012.04.029.

20. Liew, L.N., Shi, J., Li, Y. (2011). Enhancing the solid-state anaerobic digestion of fallen leaves through simultaneous alkaline treatment. Bioresource Technology,vol. 102, no. 19, 8828-8834, DOI: 10.1016/j. biortech.2011. 07.005.

21. Mirahmadi, K., Kabir, M.M., Jeihanipour, A., Karimi, K., Taherzadeh, M. (2010). Alkaline pretreatment of spruce and birch to improve bioethanol and biogas production. BioResources, vol. 5, no. 2, 928-938.

22. Antonopoulou, G., Stamatelatou, K., Lyberatos, G. (2010). Exploitation of rapeseed and sunflower residues for methane generation through anaerobic digestion: the effect of pretreatment. Chemical Engineering Transactions, vol. 20, 253-258, DOI: 10.3303/CET1020043.

23. Monlau, F., Latrille, E., Da Costa, A.C., Steyer, J.P., Carrere, H. (2013). Enhancement of methane production from sunflower oil cakes by dilute acid pretreatment. Applied Energy,vol. 102, 1105-1113, DOI: 10.1016/j.apenergy.2012. 06.042.

24. Keshwani, D.R., Cheng, J.J. (2010). Microwav based alkali pretreatment of switchgrass and coastal bermudagrass for bioethanol production. Biotechnology Progress,vol. 26, no. 3, 644-652, DOI: 10.1002/ btpr.371.

25. Mood, S.H., Golfeshan, A.H., Tabatabaei, M., Jouzani, G.S., Najafi, G.H., Gholami, M., Ardjmand, M. (2013). Lignocellulosic biomass to bioethanol, a comprehensive review with a focus on pretreatment. Renewable and Sustainable Energy Reviews, vol. 27, 77-93, DOI: 10.1016/j.rser.2013.06.033.

26. Cesaro, A., Naddeo, V., Amodio, V., Belgiorno, V. (2012). Enhanced biogas production from anaerobic codigestion of solid waste by sonolysis. UItrasonics Sonochemistry, vol. 19, no. 3, 596-600, DOI: 10.1016/j.ultsonch.2011.09.002.

27. Fatriasari, W., Syafii, W., Wistara, N., Syamsu, K., Prasetya, B. (2016). Lignin and cellulose changes of betung bamboo (Dendrocalamus asper) pretreated microwave heating. International Journal on Advanced Science, Engineering and Information Technology, vol. 6, no. 2, 186-195, DOI: 10.18517/ ijaseit.6.2.688.
28. Sapci, Z. (2013). The effect of microwave pretreatment on biogas production from agricultural straws. Bioresource Technology, vol. 128, 487-494, DOI: 10.1016/j.biortech.2012.09.094.

29. Fatriasari, W., Syafii, W., Wistara, N., Syamsu, K., Prasetya, B. (2014). The characteristic changes of betung bamboo (Dendrocalamus asper) pretreated by fungal pretreatment. Int J Renew Energy Dev, vol. 3, no. 2, 133-143, DOI: 10.14710/ijred.3.2. 133-143.

30. Ishola, M., Millati, R., Syamsiah, S., Cahyanto, M., Niklasson, C., Taherzadeh, M. (2012). Structural changes of oil palm empty fruit bunch (OPEFB) after fungal and phosphoric acid pretreatment. Molecules, vol.17, no. 12, 14995-15012, DOI: 10.3390/ molecules171214995.

31. Risanto, L., Anita, S., Fatriasari, W., Prasetyo, K. (2012). Biological pretreatment of oil palm empty fruit bunch fiber by mixed culture two white rot fungi. Proceedings of the 5th Indonesian Biotechnology Conference An International Forum. Mataram, Indonesia. pp. 4-7.

32. Zhang, Q., He, J., Tian, M., Mao, Z., Tang, L., Zhang, J., Zhang, H. (2011). Enhancement of methane production from cassava residues by biological pretreatment using a constructed microbial consortium. Bioresource Technology,vol. 102, no. 19, 8899-8906, DOI: 10.1016/j.biortech.2011. 06.061.

33. Romano, R.T., Zhang, R., Teter, S., McGarvey, J.A. (2009). The effect of enzyme addition on anaerobic digestion of JoseTall Wheat Grass. Bioresource Technology, vol. 100, no. 20, 4564-4571, DOI: 10.1016/j.biortech.2008.12.065.

34. Zieminski, K., Romanowska, I., Kowalska, M. (2012). Enzymatic pretreatment of lignocellulosic wastes to improve biogas production. Waste Management,vol. 32, no. 6, 1131-1137, DOI: 10.1016/j.wasman. 2012.01.016.

35. Matin, H.H.A. (2018). Biogas production from rice husk waste by using solid state anaerobic digestion (SSAD) method. E3S Web of Conferences. EDP Sciences. vol. 31, pp. 02007, DOI: 10.1051/e3sconf/2018 3102007

36. Fatriasari, W., Hermiati, E. (2016). Lignocellulosic biomass for bioproduct: its potency and technology development. Journal of Lignocellulose Technology, vol. 1, no. 1, 1-14.

37. Liu, Q., Wang, S., Zheng, Y., Luo, Z., Cen, K. (2008). Mechanism study of wood lignin pyrolysis by using TG-FTIR analysis. Journal of Analytical and Applied Pyrolysis, vol. 82, no. 1, 170-177, DOI: 10.1016/j. jaap.2008.03.007.

38. Novia, S., Purboyo, G.T. (2017). Pengaruh konsentrasi natrium hidroksida saat pretreatment dan waktu fermentasi terhadap kadar bioetanol dari daun nanas. Jurnal Teknik Kimia, vol. 21, no. 3, 16-26. 
39. Permana, W.S., Nugraha, W.D., Syafrudin, S. (2017). Pengaruh perlakuan pendahuluan $\mathrm{NaOH}$ terhadap produksi biogas dari limbah sekam padi dengan metode Solid State Anaerobic Digestion (SS-AD). Jurnal Teknik Lingkungan, vol. 6, no. 3, 1-11.

40. Saritha, M., Arora, A. (2012). Biological pretreatment of lignocellulosic substrates for enhanced delignification and enzymatic digestibility. Indian journal of microbiology, vol. 52, no. 2, 122-130, DOI: 10.1007/ s12088-011-0199x.

41. Kinney, T., Masiello, C., Dugan, B., Hockaday, W., Dean, M., Zygourakis, K., Barnes, R. (2012). Hydrologic properties of biochars produced at different temperatures. Biomass and Bioenergy,vol. 41, 3443, DOI: 10.1016/j.biombioe.2012.01.033.

42. Thaiyibah, N., Alimuddin, A., Panggabean, A.S. (2016). Pembuatan dan karakterisasi membran selulosa asetat-pvc dari eceng gondok (Eichhornia crassipes) untuk adsorpsi logam tembaga (II). Jurnal Kimia Mulawarman, vol. 14, no. 1, 29-35.

43. Zhang, F., Zhu, Z., Wang, B., Wang, P., Yu, G., Wu, M., Chen, W., Ran, W., Shen, Q. (2013). Optimization of Trichoderma harzianum T-E5 biomass and determining the degradation sequence of biopolymers by FTIR in solid-state fermentation. Industrial Crops and Products, vol. 49, 619-627, DOI: 10.106/j. indcrop.2013.05.037.

44. Nishiyama, S., Okazaki, M., Katsumi, N., Honda, Y., Tsujimoto, M. (2015). Surface charge on sago starch granules. Sago Palm, vol. 23, 77-83.

45. Sembiring, M.T., Sinaga, T.S. (2003). Arang Aktif (Pengenalan dan Proses Pembuatannya), 1-9.

46. Xiao, X., Bian, J., Li, M.-F., Xu, H., Xiao, B., Sun, R.C. (2014). Enhanced enzymatic hydrolysis of bamboo (Dendrocalamus giganteus Munro) culm by hydrothermal pretreatment. Bioresource Technology, vol. 159, 41-47, DOI: 10.1016/j.biortech.2014. 02.096.

47. Rambat, R., Aprilita, N.H., Rusdiarso, B. (2015). Aplikasi limbah kulit buah kakao sebagai media fermentasi asam laktat untuk bahan baku bioplastik. Jurnal Kimia dan Kemasan, vol. 37, no. 2, 111-122, DOI: 10.24817/jkk.v37i2.1820.
48. Dewi, A.M.P., Kusumaningrum, M.Y., Edowai, D.N., Pranoto, Y., Darmadji, P. (2017). Ekstraksi dan karakterisasi Selulosa dari limbah ampas sagu. Prosiding SNST Fakultas Teknik, vol. 1, no. 1, 6-9.

49. Xu, G., Wang, L., Liu, J., Wu, J. (2013). FTIR and XPS analysis of the changes in bamboo chemical structure decayed by white-rot and brown-rot fungi. Applied Surface Science, vol. 280, 799-805, DOI: 10.1016/j.apsusc.2013.05.065.

50. Fang, C., Schmidt, J.E., Cybulska, I., Brudecki, G.P., Frankaer, C.G., Thomsen, M.H. (2015). Hydrothermal pretreatment of date palm (Phoenix dactylifera L.) leaflets and rachis to enhance enzymatic digestibility and bioethanol potential. BioMed Research International, vol. 2015, 1-13, DOI: 10.1155/2015/216454.

51. Rahmidar, L., Wahidiniawati, S., Sudiarti, T. (2018). Pembuatan dan karakterisasi metil selulosa dari bonggol dan kulit nanas (Ananas comosus). Alotrop, vol. 2, no. 1, 88-96.

52. Nomanbhay, S.M., Hussain, R., Palanisamy, K. (2013). Microwave-assisted alkaline pretreatment and microwave assisted enzymatic saccharification of oil palm empty fruit bunch fiber for enhanced fermentable sugar yield. Journal of Sustainable Bioenergy Systems, vol. 3, no. 1, 7-17, DOI: 10.4236/ jsbs.2013.31002.

53. Santoso, B., Sakakura, K., Naito, H., Ohmi, M., Nishimura, Y., Uchiyama, T., Itaya, A., Hisamatsu, M., Ehara, H., Mishima, T. (2015). Effects of micro powder milling on physicochemical properties of sago starch. Journal of Applied Glycoscience, vol. 62, no. 2, 73-80, DOI: 10.5458/jag.jag.JAG-2015_008.

54. Hidayat, M.R. (2013). Bahan lignoselulosa dalam proses produksi bioetanol. Biopropal Industri, vol. 4, 33-48. 